\title{
Comparative Anatomical, Light and Scanning Electron Microscopical Studies Between Intromittent and Non-Intromittent Typed Phallus of Domestic Goose (Anser anser domestica) and Turkey (Meleagris gallopavo domestica)
}

\author{
Samah H El- Bably ${ }^{1 *}$ and Shaymaa Hussien ${ }^{2}$ \\ ${ }^{1}$ Department of Anatomy and Embryology, Faculty of Veterinary Medicine, Cairo University, Giza, Egypt \\ ${ }^{2}$ Department of Histology and cytology, Faculty of Veterinary Medicine, Cairo University, Giza, Egypt \\ *Corresponding author: drsamah_elbably@yahoo.com, Alternative email: samah.hussien@cu.edu.eg
}

\begin{abstract}
Article History: 20-073 Received: 22-Mar-20 $\quad$ Revised: 04-Jun-20 $\quad$ Accepted: 17-Jun-20
ABSTRA CT

The work applied on the phallus of the adult goose and turkey to give knowledge for the phallus functional morphology and the mechanism of copulation of these domestic birds. It helped the surgical interfering of the wild geese and the artificial insemination in the turkey for commercial production. The phallus of the goose and the phallic bodies of the turkey were demonstrated by anatomical, histological, histochemical and scanning electron microscopy to compare the micromorphological features. The goose has an intromittent type phallus. It consisted of inner glandular part and outer cutaneous one. The former lined by mucous secretory cells, while the later cover externally by stratified squamous nonkeratinized epithelium. The turkey phallus was a non-intromittent type. It composed of a median phallic furrow on the crest at the ventral vent lip and flanked on either side by lateral phallic bodies. The later lined by stratified squamous non-keratinized and supported by longitudinal oriented skeletal muscle which circular in the furrow between two phallic bodies. Additionally, lymphatic aggregation was observed in phallus of two birds. This study helped in comparative studies and surgical operations.
\end{abstract}

Key words: Phallus, Copulatory organ, Goose, Turkey, Scan electron microscope.

(C2020 IJVS - All Rights Reserved

\section{INTRODUCTION}

Several studies applied by many authors on the male reproductive system of the fowl (Tingari 1971; Amer and Shahin 1975). The avian male external genitalia showed a great anatomical variation in size and shape even between closely related species. All birds reproduced by internal fertilization except the phallus of some species of birds could be capable of intromission, so the phallus had a variety of forms according to its anatomical structures (Hosken and Stockley 2004).

The avian phallus is divided into three categories, the first was the intromittent type that is divided into two types according to presence or absence of a blind tubular cavity within the phallus. The blind cavity absents in kiwis and ostrich, while it is present in duck and goose, this type of phallus is entered the female cloaca during coitus. The second was the non-intromittent type, which was a reduced type but not lost, as in the fowl and turkey and some song birds, this type did not enter the female cloaca but deposited the semen outside on the female external genitalia. The third one involved a complete absence of the phallus as in pigeon (Briskie and Montgomeric 1997; Chen 2005; Brennan et al. 2008; Herrera et al. 2013).

\section{MATERIALS AND METHODS}

\section{Animal ethics}

All animal related procedures in the study were approved ethically by Cairo University institutional animal care and use committee (CU-IACUC). Approval document number is CU-11-F-32-19. The study was applied on seemingly healthy adult ten male native geese and turkeys, weighting $4.5-6 \mathrm{~kg}, 3.5-5 \mathrm{~kg}$ respectively; they were obtained from the chicken farmhouses around Cairo, Egypt.

\section{Gross anatomical study}

The phallus was seen in situ at the ventral lip of the vent in the turkey, while laid in a phallic pouch close to cloaca in goose. By using $50 \mathrm{~cm}$ syringe filled with warm saline solution, its nozzle was introduced into the phallic

Cite This Article as: El-Bably SH and Hussien S, 2021. Comparative anatomical, light and scanning electron microscopical studies between intromittent and non-intromittent typed phallus of domestic goose (Anser anser domestica) and turkey (Meleagris gallopavo domestica). International Journal of Veterinary Science 10(1): 19-24. https://doi.org/10.47278/journal.ijvs/2020.020 
pouch and injected with $10 \%$ normal saline solution, the phallus could be everted outside the pouch, passed into caudal direction, through the vent, the length could be measured during erection by using a ruler, also could be demonstrated by the morphology and different parts (Reilly 2001). Sony digital camera $24 \mathrm{mp}, 18 \mathrm{x}$ was used for photographed the existing results. The nomenclature recommended in this study was given by Nomina Anatomica Avium.

\section{General histological study}

After complete anesthesia, the birds were slaughtered and the phallus of both birds was immediately dissected out and sectioned into small pieces. The specimens were fixed in neutral buffered formalin. They were dehydrated in ascending degree of alcohols, cleared in benzene finally embedded in paraplast. Serial and step serial sections of 5$6 \mu \mathrm{m}$ thick were obtained and stained with Hematoxylin and Eosin (H\&E), Masson's trichrome (Bancroft and Gamble 2008).

\section{Histochemical study}

The specimens were obtained, fixed and processed as listed in general histological study and Periodic Acid Schiff technique (PAS) stained for neutral mucopolysaccharides detection Carson (1990).

\section{Scanning electron microscope}

Small specimens taken from phallus of geese and turkeys were washed by $0.1 \mathrm{M} \mathrm{Na-cacodylate} \mathrm{buffer.} \mathrm{They}$ were fixed in a mixture of $2.5 \%$ paraformaldehyde and $2.5 \%$ glutaraldehyde in $0.1 \mathrm{M} \mathrm{Na}$-cacodylate buffer, $\mathrm{pH} 7.3$ for 4 hours at $4{ }^{\circ} \mathrm{C}$, thereafter, they were washed in the same buffer used and post-fixed in $1 \%$ osmic acid in $0.1 \mathrm{M} \mathrm{Na}-$ cacodylate buffer for further $2 \mathrm{~h}$ at room temperature. The samples were dehydrated and critical point dried with a polaron apparatus. Finally, they were coated with gold and observed with JEOL scanning electron microscope (JSM5400 LV) at KV 10 Polák et al. (1983). All specimens were prepared and analyzed in electron microscope Unit, of applied centre for entomonematodes, Faculty of Agriculture, Cairo University, Egypt.

\section{RESULTS}

The phallus was the organ of copulation in the male's birds, could be categorized into two types, true intromittent phallus, which was introduced into the female cloaca during coitus and non-intromittent phallus was not entered the cloaca but it expelled the sperms onto the external female genitalia directly.

\section{Goose anatomical finding}

The phallus was an intermittent type (phallus protrudens). It was a spiral-coiled organ. At the rest state, the phallus of goose was invested within a double peritoneal membrane called phallic pouch, slightly sited left to median plane close to the cloaca. It was about 2 and half coils, organized in an anticlock wise direction (Fig. $1 \mathrm{~A} / 1)$ and these coils were arranged as a double U-shaped tube that were formed of a thick, large part twisted by a small, thin tube, in between the phallic flexure (Flexura phalli) (Fig. 1B/2). The large thick part called cutaneous sac (sacci cutanei phalli) (Fig. 1B/3), and the small thin one called glandular sac (sacci glandularis phalli) (Fig. 1B/4) At erected state the phallus was a very long structure composed of base, body and apex, its length was about 8 $10 \mathrm{~cm}$. The shaft of the phallus (Fig. 1B/5), was demarcated by a phallic sulcus (sulcus phalli) which was a spirally longitudinal groove, placed between two tubes of the phallus, extended from the ejaculatory fossa to the apex of the phallus called sulcus spermaticus (Fig. 1B/6). Also, the body was characterized by presence of phallic ridges spread all over the phallus, arranged in a numerous row, these ridges were pointed and directed backward towards the base called rugae phalli (Fig. 2/1). The base of the phallus (Fig. 3A) supported by a cartilaginous body (corpus cartilaginous) (Fig. 3B/4). The suspensory ligament of the phallus is called suspensorium phalli (Fig. 3C/6). The apex of the phallus (apex phalli erecti) was the terminal part of the phallus (Fig. 3D/7), it had the opening of glandular sac (ostium sacci glandularis phalli) that allowed the seminal fluid to be come out from the phallus (Fig. 3D/8).

\section{Goose histological finding}

Histologically, the phallus of goose consisted of the inner glandular part and outer cutaneous layer. The inner glandular part was lined with mucous secretary cells and contained mucous gland (Figs. 4A, 4B and 4C) whose revealed PAS positive reaction (Fig. 4D) and surrounded by outer cutaneous layer of collagen fibers (Fig. 5A); the latter layer was composed of two distinct parts: an inner

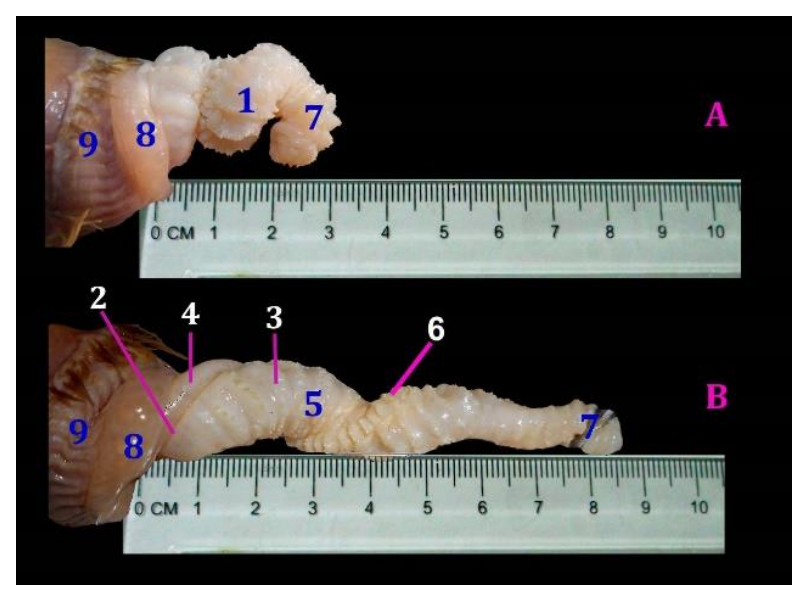

Fig. 1: A photograph showing the length and parts of erected pallus of the male goose. A: Length of the flaccid phallus. B Length of the fully erected phallus. 1) anticlock wise coils, 2) phallic flexure, 3) cutaneous sac, 4) glandular sac, 5) body, 6) spermatic sulcus, 7) apex, 8) base and 9) vent.

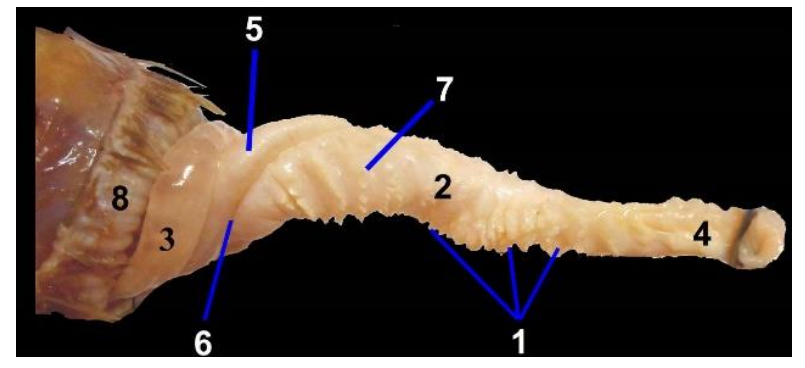

Fig. 2: A photograph showing a fully erected goose phallus consisted of 1) phallic ridges, 2) body, 3) base, 4) apex, 5) glandular sac, 6) phallic flexure, 7) cutaneous sac and 8) vent. 
Int J Vet Sci, 2021, 10(1): 19-24.

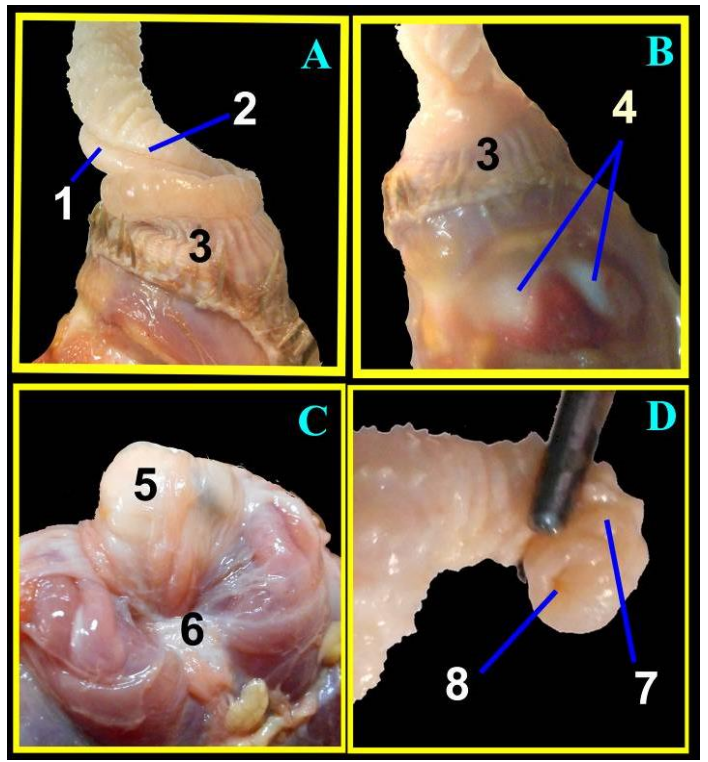

Fig. 3: A photograph showing the different parts of the phallus in the male goose. A: Base, B: Cartilaginous body, C: Phallic pouch and D: Apex and opening of glandular sac. Other parts are 1) glandular sac, 2) cutaneous sac, 3) vent, 4) hyaline cartilage, 5) phallic pouch, 6) suspensory ligament, 7) apex and 8) opening of glandular sac.

Fig. 4: A transverse section of goose phallus, A: Scanning electron microscopy showing inner glandular part (I) $\quad($ Bar $=500 \mu \mathrm{m}) ; \quad$ B: A photomicrograph showing inner glandular part (I) and outer collagenous part $(\mathrm{O}), \mathrm{H} \& \mathrm{E}$ stain, $\mathrm{X} 40$; $\mathrm{C}$ : Scanning electron microscopy showing mucous secretory cells (arrow) and lymphatic capillaries (L) $($ Bar $=100 \mu \mathrm{m})$, and D: A photomicrograph showing inner glandular part lined with PAS positive mucous secretory cells (arrow) and mucous gland (double arrows). PAS stain $(\mathrm{X} 400)$.
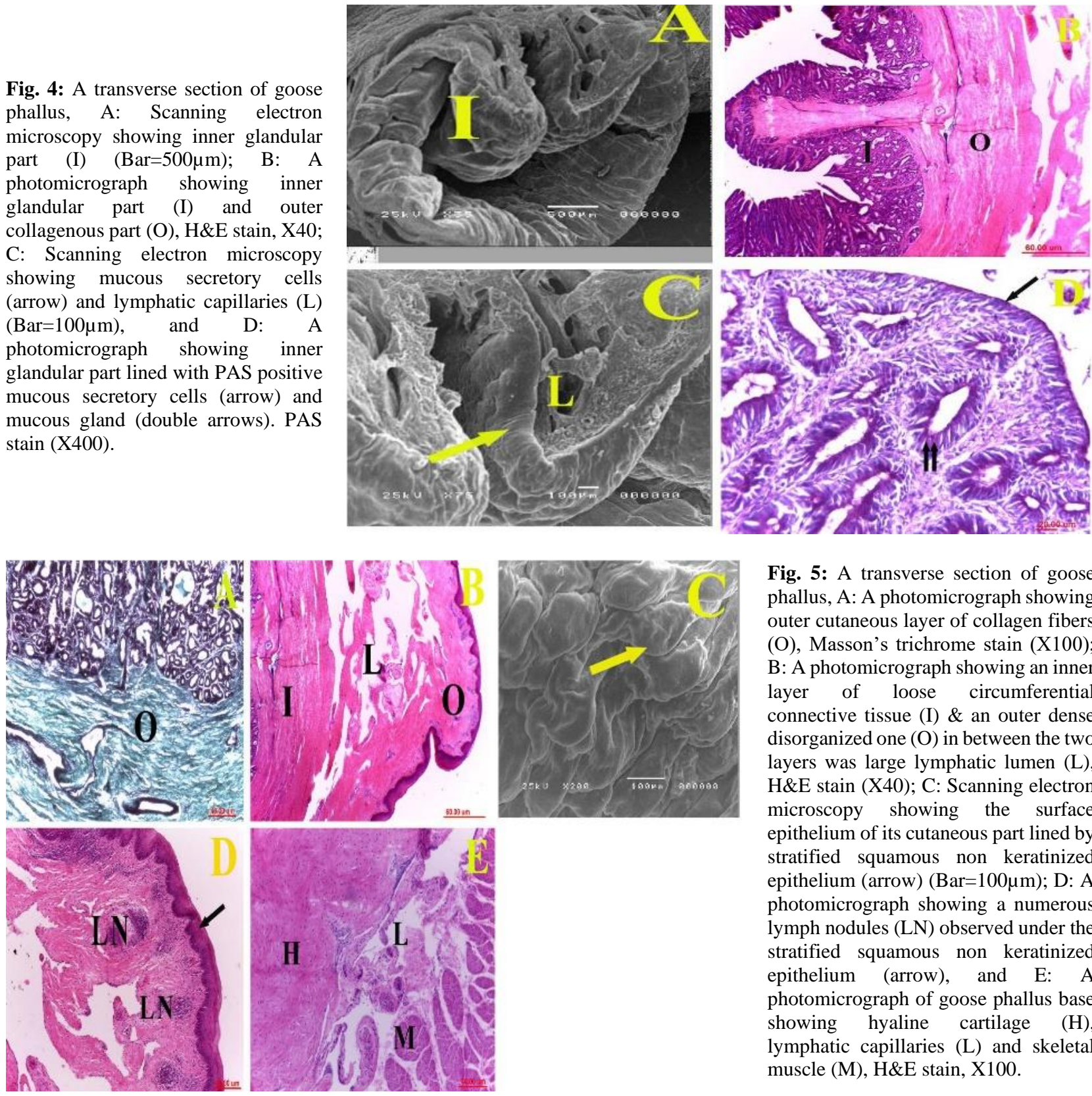

Fig. 5: A transverse section of goose phallus, A: A photomicrograph showing outer cutaneous layer of collagen fibers (O), Masson's trichrome stain (X100); B: A photomicrograph showing an inner layer of loose circumferential connective tissue (I) \& an outer dense disorganized one $(\mathrm{O})$ in between the two layers was large lymphatic lumen (L), H\&E stain (X40); C: Scanning electron microscopy showing the surface epithelium of its cutaneous part lined by stratified squamous non keratinized epithelium (arrow) (Bar=100 $\mu \mathrm{m})$; D: A photomicrograph showing a numerous lymph nodules (LN) observed under the stratified squamous non keratinized epithelium (arrow), and E: A photomicrograph of goose phallus base showing hyaline cartilage $(\mathrm{H})$, lymphatic capillaries (L) and skeletal muscle (M), H\&E stain, X100. 


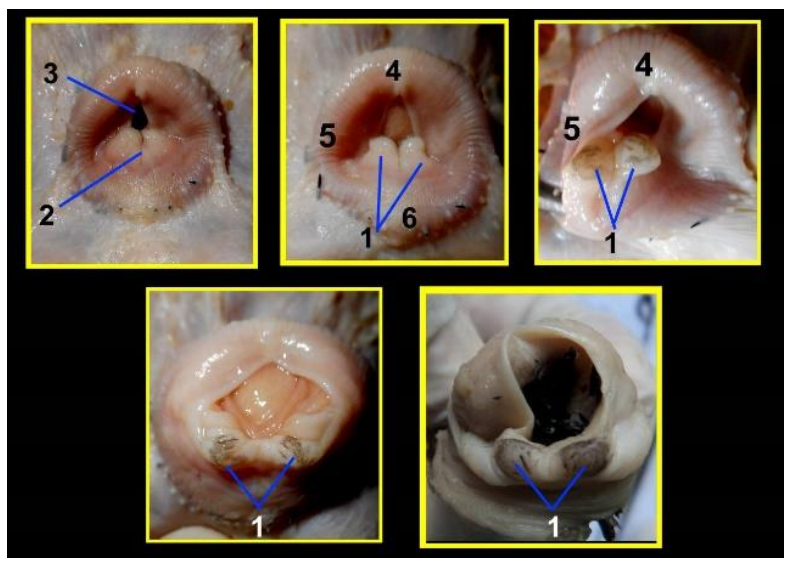

Fig. 6: A photograph showing the phallus in the male Turkey. Various parts are 1) lateral phallic bodies, 2) median furrow, 3) opening of the vertical fissure, 4) dorsal lip, 5) vent and 6) ventral lip.

layer of loose circumferential and an outer dense disorganized layer in between the two layers was large lymphatic lumen (Fig. 5B), as well as lymphatic capillaries were observed in the connective tissue beneath the glandular portion (Fig. 4C). The surface epithelium of its cutaneous part was lined by stratified squamous non keratinized epithelium Fig. (5C). Numerous lymph nodules were observed under the epithelium (Fig. 5D). The base of the phallus was supported by hyaline cartilage, lymphatic capillaries and skeletal muscle (Fig. 5E).

\section{Turkey anatomical findings}

The male copulatory organ was appeared in the ventral wall of the vent; it was non intromittent type. It was composed of two lateral phallic bodies on each side at the ventral wall of the vent (Fig. 6/1), separated by a median furrow or groove (Fig. 6/2). Two lateral phallic bodies were appeared as a short, rounded structure, which was enlarged and engorged with fluid; the fluid passed into the median furrow.

\section{Turkey histological findings}

The phallus of turkey was formed of cutaneous portion only (Fig. 7A) lined with stratified squamous non keratinized epithelium (Fig. 7B) and characterized by neither tubular nor glandular portion detected. This cutaneous portion was arranged as two plugged portions, lateral phallic bodies (Fig. 7A), connected by furrow. Longitudinal oriented skeletal muscle was observed in the phallic body while circular orientation in the furrow (Figs. 7C and 8A). Highly vascularized and innervated dense irregular connective tissue mainly collagen fibres with peripheral nerve ending, lamellar corpuscle, were observed beneath the stratified squamous non keratinized epithelium (Figs. 7C and 8B). Lymphatic nodules were detected beneath the epithelium in the phallic bodies as well as at commissure between the phallic bodies and the furrow (Figs. 8C and 8D).

\section{DISCUSSION}

The present study revealed that, the phallus of the goose was an intromittent type, it was a spiral coiled structure invested within a double peritoneal membrane (Phallic pouch), similar to King (1981), Kevin (2000), Brennan et al. (2009) and El Gindy et al. (2016) in duck and King and McLelland (1984), Brennan and Prum (2012) in Ostrish and kiwis and Rajendranath et al. (2013) in emu, while, the phallus of the turkey was an non intromittent type and lied on the crest of the ventral lip of the vent, these results similar to the results in the domestic fowl that were confirmed by Bull et al. (2007).

The coils of phallus were about 2 and half coils, had a anticlock wise direction, but El Gindy et al. (2016) in balady duck recorded 3 and half coils. When dissected it was seen as a U-shaped tube, attached to the cloaca at both ends that simulated Kevin (2000) in Argentine duck and El Gindy et al. (2016) in balady duck and. This tube is formed of two parts; thick and thin tubes in between phallic flexure the thick part is called cutaneous sac while, the thin one is called glandular sac similar to the findings of King and McLelland (1984), Baumel et al. (1993) and El Gindy et al. (2016) in duck, but in this study, the two tubes in the goose were a very characteristic than the same tubes in the duck as the cutaneous tube was a very larger than the glandular one.
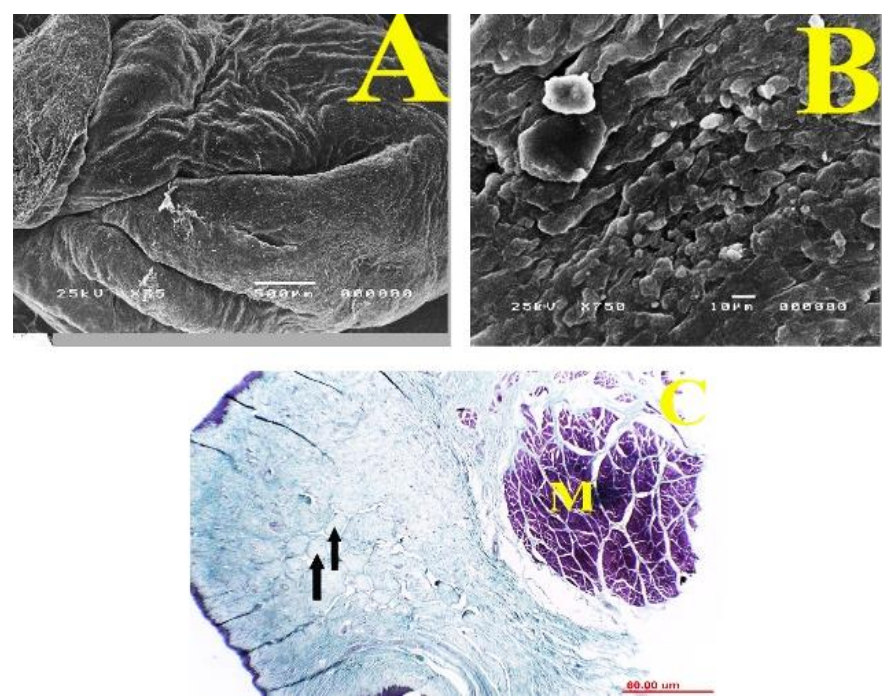

Fig. 7: A transverse section of turkey phallus. A: Scanning electron microscopy showing the cutaneous portion in the phallic body $(\mathrm{Bar}=500 \mu \mathrm{m})$; B: Scanning electron microscopy showing the cutaneous portion lined by stratified squamous non keratinized $(\mathrm{Bar}=10 \mu \mathrm{m})$ and $\mathrm{C}: \mathrm{A}$ photomicrograph showing longitudinal oriented skeletal muscle (M) and lamellar corpuscle (arrow) in the phallic body, Masson's trichrome stain, Bar= $60 \mu \mathrm{m}$. 


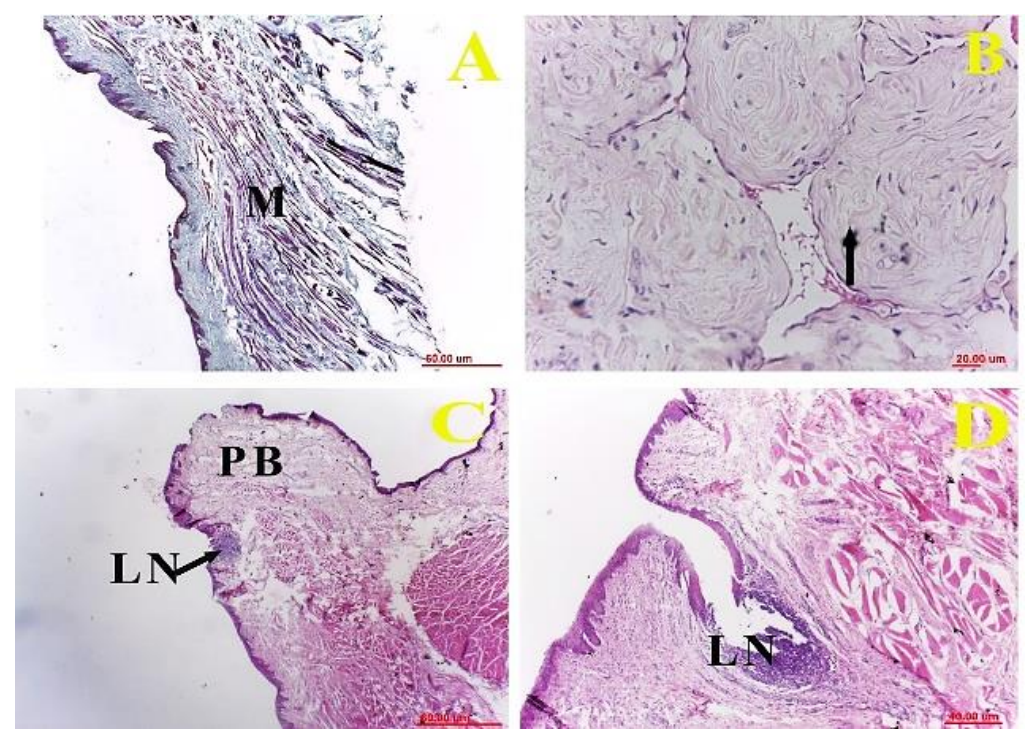

Fig. 8: A transverse section of turkey phallus. A: A photomicrograph showing circular oriented skeletal muscle (M) in the furrow, Masson's trichrome stain, X40; B: A photomicrograph showing lamellar corpuscle (arrow) in the phallic body, H\&E stain, X400; C: A photomicrograph showing lymphatic nodule $(\mathrm{LN})$ in the phallic body $(\mathrm{PB})$, H\&E stain, $X 40$ and $D: A$ photomicrograph showing lymphatic nodule at the commissure between the phallic body and the furrow (LN), $\mathrm{H} \& \mathrm{E}$ stain, X100

In the turkey, the phallus was formed of two lateral phallic bodies on each side at the ventral wall of the vent. Two lateral phallic bodies were appeared as a short, rounded structure, separated by a median furrow, these results were confirmed by Bull et al. (2007) in fowl but the author reported presence of a median phallic body between the two phallic bodies, which was not found in the turkey in this study and also stated that, the deposited semen became outside the female cloaca, on the everted vagina during copulation process, then the spermatozoa transported into the oviduct. In goose, the large cutaneous sac of phallus was characterized by a spirally longitudinal phallic sulcus that was extended from the base to the apex, also called sulcus spermaticus due to the sperms transported through this groove. The results are in line with the previous studies of King (1981), Duan (2000), El Gindy et al. (2016) in balady duck, Wang et al. (2008) in goose, while Yong and Zhanjun (2011) in ostrich recorded a penile groove at the back of the penis which was a closed and like a tube when the penis erected.

In this study, the fully erected phallus of goose was consisted of a large left and a small right tube twisted around each other, which formed a bulbous base, body and terminated by the apex of the phallus, as recorded by King and McLelland (1984) in duck. These regions were found in the phallus of all types of Anseriforms but the divisions of these regions differed according to each author, as Brennan et al. (2009) in Muscovy duck divided it into basal and apical regions, Baumel et al. (1993) in duck demonstrated four components, phallic base, phallic body, phallic sac and phallic pouch. While in the turkey, the phallus was composed of a median phallic groove flanked on either side by lateral phallic bodies. Regarding the total length of the phallus, it was ranged from $8-10 \mathrm{~cm}$ during fully erection in goose, while, reached $22 \mathrm{~cm}$ in Argentine duck (Kevin 2000), 20cm in ostrich (Elias et al. 2007; Brennan and Prum 2012), 25-30cm in ostrich (Yong and Zhanjun 2011) who stated that this penis was very strong, while the penis of the turkey as in chickens was not strong, $3 \mathrm{~cm}$ in rhea (Góes et al. 2010), $8.5 \mathrm{~cm}$ in Laysan ducks and $5.3 \mathrm{~cm}$ in Mandarin ducks (Herrera et al. 2014) and ranged from $13-15 \mathrm{~cm}$ in Balady duck (El Gindy et al. 2016). The phallus had some black coloration on its outer surface in Mandarin ducks and also lacked this coloration in the
Laysan ducks that was recorded by Herrera et al. (2014), this coloration was not recorded in the goose in this study and also was not recorded by El Gindy et al. (2016) in Balady duck. The external surface of the phallus was characterized by presence of ridges that covering the wall of the phallus, as reported by Brennan et al. (2009) in Mallarad duck, El Gindy et al. (2016) in balady duck but this study added that these phallic ridges were pointed, distributed all over the phallus in a several rows. Meanwhile Kevin (2000) in Argentine duck reported spines directed backwards towards the base of the phallus.

The penis of goose had the inner glandular part lined with secretory cells surrounded by outer cutaneous layer of collagen fibers; the latter layer was composed of two distinct parts: an inner layer of lose circumferential and an outer dense disorganized layer in between the two layers was large lymphatic lumen. These results agreed with Brennan et al. (2009) in mallard duck, Brennan and Prum (2012) in emus, El Gindy et al. (2016) in Balady duck, while Brennan and Prum (2012) in ostrich recorded that, the penis lacked a blind tubular cavity and formed of fibrous bodies composed of dense, largely disorganized collagen matrix except in the areas surrounded the narrow lymphatic spaces.

In line with the findings of King and McLelland (1984), Brennan et al. (2009) in duck and El Gindy et al. (2016) in Balady duck, the base of phallus was supported by cartilaginous body which was formed of hyaline cartilage and its cutaneous part.

In the present study lymphocytic aggregations noticed in the phallus of goose and turkey. Lymphocytic aggregation had developed a number of different immunological strategies including cell mediated one. These lymphocytes might add a more protective condition for the sperms. In the current study, PAS reaction was detected in the surface epithelium and the gland. This revealed presence of neutral mucoplysaccharides (Zaher et al. 2012).

\section{Conclusion}

The study gives a complete knowledge for phallus of geese and turkey that will help in the surgical operations of the wild geese, and the artificial insemination in the turkey, which is an obligatory method for commercial production. 


\section{Author contributions}

All authors contributed to the reagents/materials/ analysis tools, collected the material, analyzed the data and wrote the manuscript.

\section{REFERENCES}

Amer FI and Shahin MA, 1975. The post-hatching development of the gonads in the fowl, Gallus domesticus. Annals of Zoology 11: 1-25.

Bancroft JD and Gamble M, 2008. Theory and practice of histological techniques. 6th Ed. Churchill Livingston, New York, USA.

Baumel JJ, King SA, and Breasile JE, 1993. Nomina Anatomica Avium. Published by the Nuttall Ornithological Club. No: 23, Cambridge, Massachusets.

Brennan PLR, Birkhead TR, Zyskowski K, van der Waag J and Prum RO, 2008. Independent evolutionary reductions of the phallus in basalbirds. Journal of Avian Biology 39: 487-492. https://doi.org/10.1111/j.0908-8857.2008.04610.x

Brennan PLR, Clark CJ and Prum RO, 2009. Explosive eversion and functional morphology of the duck penis supports sexual conflict in waterfowl genitalia. Proceedings of the Royal Society B, Biological Sciences 277: 1309-1314. https://doi.org/10.1098/rspb.2009.2139

Brennan PLR and Prum RO, 2012. The erection mechanism of ratite penis. Journal of Zoology 286: 140-144. https://doi/org/10.1111/j.1469-7998.2011.00858.x

Briskie JV and Montgomerie R, 1997. Sexual selection and the intromittent organ of birds. Journal of Avian Biology 28: 73-86.

Bull ML, Martins MRF, Cesario MD, Padovani CR, Mendes AA, 2007. Anatomical study on domestic fowl (Gallus domesticus) reproductive system. International Journal of Morphology 25: 709-716.

Carson FL, 1990. Histotechnology: A Self-Insructional Text. American Society of Clinical Pathologists. Chicago, pp: 294.

Chen YT, 2005. Matching methods and the relevant management skills of pigeon breeders. China Poultry, 27: 26-28.

Duan X, 2000. The main points of artificial insemination. China Poultry, 22: 17-18.

EL Gindy EM, Hassan AM, El-Bably SH, Shaker NA and Hussien SH, 2016. Morphological studies on the male copulatory organ of Balady Duck (Anas boscas domestius) with special reference to its blood supply. Giza Veterinary Medical Journal.

Elias MZJ, Aire TA and Soley JT, 2007. Macroscopic features of the arterial supply to the reproductive system of the male Ostrich
(Struthio camelus). Anatomia, Histologia, Embryologia, 36: 255-262.

Góes PAA, Cavalcante AKS, Nichi M, Perez EG de A, Barnabe RC and Barnabe VH, 2010. Reproductive characteristics of captive greater rhea (Rhea americana) males reared in the state of Sao Paulo Brazil. Brazil Journal of Poultry Science, 12: 57-62. https://doi.org/10.1590/S1516-635X2010000100 $\underline{009}$

Herrera AM, Brennan PLR and Cohn MJ, 2014. Development of avian external genitalia: interspecific differences and sexual differentiation of the male and female Phallus. Sexual Development, 9: 43-52.

Herrera AM, Shuster SG, Peritton CL and John MJ, 2013. Developmental basis of Phallus reduction during bird evolution. Current Biology, 23: 1065-1075. https://doi.org/10.1016/j.cub.2013.04.062

Hosken DJ and Stockley P, 2004. Sexual selection and genital evolution. Trends in Ecology \& Evolution 19: 87-93.

Kevin GMC, 2000. The 20-cm spiny penis of the Argentine Lake Duck (Oxyura vittata). The Auk 117: 820-825.

King AS, 1981. Phallus. In form and function in birds. Academic Press, New York, USA, pp: 107-148.

King AS and McLelland J, 1984. Birds, Their Structure and Function. $2^{\text {nd }} E d$, Bailliere Tindall, England: pp: 145-165.

Polák Š, Brozman M and Jakubovský J, 1983. Concerning problem of applying raster electron microscopy in studying the ortho- and pathomorphology of the human spleen. Bratislava Lekarske Listy 80: 267-278.

Rajendranath N, S Chandrasekhara RT, Kumar PD, Raghavendar $\mathrm{K}$ and Kumar V, 2013. Gross anatomical studies on the apparatus of the Emu (Dromaius novaehollandiae). Indian Journal of Veterinary Anatomy 25: 81-82.

Reilly JS, 2001. Euthanasia of animals used for scientific purposes; section 13: Birds (Class Aves), ANZCCART, $2^{\text {nd }}$ Ed. pp: 79-82.

Tingari MD, 1971. On the structure of the epididymal region and ductus deferens of the domestic fowl (Gallus domesticus). Journal of Anatomy, 109: 423-435.

Yong $\mathrm{Z}$ and Zhanjun R, 2011. Anatomic study on the main male reproductive organs of Ostrich. Global Journal of Health Science 3: 2011.

Wang, Wenqiang and Huaqi Z, 2008. Artificial insemination technology and the application in Goose. China Poultry, 30: 37-38.

Zaher M, El_Ghareeb AW, Hamdi $\mathrm{H}$ and and AbuAmod F, 2012. Histochemical adaptation of avian alimentary canal to their food habits. I: Coturnix coturnix. Life Science Journal 9: 253-275. 